\title{
A GLOBAL GLANCE AT COVID-19 EDUCATION PROCESS AND CONSIDERING TURKEY'S COVID-19 RESPONSE
}

\author{
RESEARCH ARTICLE
}

\section{Seda DEMIR ${ }^{1}$}

1 Dr., İngilizce Öğretmeni, Sakarya Serdivan Anadolu Lİsesi, MEB, seda.erkoc1@ogr.sakarya.edu.tr, ORCID: 0000-0002-3044-8530.

\begin{abstract}
:
Coronavirus disease which spread around the world from China where it emerged in the early months of 2020, is a severe, fatal, and highly infectious disease mostly resulting in severe acute respiratory and related syndrome. In this context, following the school closures on a global scale, millions of students needed to catch up with the rest of the curriculum on-line or continue learning distantly under the guidance of their instructors through on-line learning tools, do various on-line assignments from other on-line sources alternatively depending on their preferences. The study aims at detailing the Covid-19 process for $\mathrm{K}-12$ education in the world in contrast with Turkey. The study mentions some common distance education characteristics on global scale and that education response of Turkey was highly effective compared to many others. The inferences can lead the education specialists in terms of helping their governments create smoother and more in-line situations for distance education for "new-normal" processes.
\end{abstract}

Keywords: distance education, Covid-19 pandemic, school-closure, on-line learning/teaching 


\title{
COVID-19 EĞiTIM SÜRECINE KüRESEL BIR BAKIŞ VE TÜRKIYE'NIN BU SÜREÇTEKI EĞITIM REAKSIYONLARININ DEĞERLENDIRILMESI
}

\begin{abstract}
Öz: 2020 yılının ilk aylarında ortaya çıktığ 1 Çin'den dünyaya yayılan Corona virüsü hastalığı, çoğunlukla şiddetli akut solunum yolu ve buna bağlı sendromlarla sonuçlanan ciddi, ölümcül ve oldukça bulaşıcı bir hastalıktır. Bu bağlamda, okulların dünya genelinde kapanmasının ardından, milyonlarca öğrencinin müfredatın geri kalanını çevrimiçi olarak takip etmesi veya eğitmenlerinin rehberliğinde çevrimiçi araçlarla uzaktan öğrenmeye devam etmesi, çeşitli çevrimiçi ödevler yapması, diğer çevrimiçi kaynaklardan alternatif şekillerde çalışması gerekmiştir. Çalışma, K-12 eğitim seviyelerindeki uzaktan eğitim sürecini Türkiye örneği merkezinde kıyaslamalı olarak dünya genelinde detaylandırmayı amaçlamaktadır. Çalışma, Türkiye'nin pandemi sürecinde eğitime verdiği reaksiyonun küresel ölçekte çoğu ülkeye kıyasla oldukça etkili olduğunu göstermektedir. Çalışma içindeki bazı global çaplı bilgi, tespit ve çıkarımlar, eğitim uzmanlarının "yeni-normal" olarak betimlenen süreçte hükümetlerine uzaktan eğitim için daha sorunsuz ve daha uyumlu eğitim ortamları hazırlamaları noktasında yardımcı olabilir.
\end{abstract}

Anahtar Kelimeler: uzaktan eğitim, Covid-19 Pandemisi, okulların kapanması, internetten öğretim/öğretnim

\section{Introduction:}

The pandemic has been so deeply effective and potentially fatal that educational institutions at all levels from pre-school to higher education were rapidly and successively closed around the world and almost all countries have attempted to continue providing their services on-line. This challenge has featured the term "distant education" and made it stand out as a new form of learning rather than teaching for the future years depending on the idea that there can likely be a similar phenomenon. While some higher educational implementations in universities and academies were present before the pandemics, they were limited with the curriculum of specific programs, and it was quite new to apply with the whole educational systems from the scale of pre-school to higher educational institutions, in other words: for $\mathrm{K}-12^{1}$ education in many parts of the world.

$1 \mathrm{~K}-\mathbf{1 2}$ education is the educational span in a child's school life starting from kindergarten to 12th grade, which indicates the range of years of government- supported pre-school, primary, and secondary education found in Turkey. Several countries from different parts of the world like Australia, USA, Canada, China, Iran, South Korea, and Egypt. In Turkey K-12 can be summarized as: Pre-primary education: optional and for children between ages 3 - 6

Primary education: This level is compulsory and held on two levels. The first level involves grades 1-4 and children between ages 6-9 while the second level involves grades 5-8 and children ages between 10-14

Secondary education: This educational level is again compulsory for children between ages 14 - 18, and high school types in Turkey vary in categories like general (Anatolian High Schools), technical and vocational high schools. 
The physical and academic conditions under the recent pandemic effects have been novel in educational milieus and in literature which has been a lacking comprehensive set of studies for depicting the global educational settings at the time. The aim of the study, hence, is to investigate how some prominent countries held their distance education and how their responses were when compared to Turkey. The study is also important for presenting a general glimpse of distance education approaches around the world which were inevitably applied in pandemic education responses. As the pandemic has still been effective in many parts of the world, a large scale of study data and info were driven from reports of authorized educational associations and organizations' reports, pre-reports, intelligence agencies' news published in their websites, surveys carried out or published on-line, etc. which is the result of on-going and unique character of the factors for school closures and lack of available published documents in the present literature.

The methodology in the study constitutes a hybrid use of literature review, compiling- the current Covid-19 related educational advancements which require chronological sequencing and interpreting the data accordingly.

\section{On Several Covid-19 Countries and Their National Education Responses}

The most overt effect of the pandemic on education globally have been school closures. According to the World Health Organization's “Coronavirus Disease 2019 (COVID-19) Situation Report" school closures due to the novel coronavirus have affected over 1.5 billion children and young people around the world. Several countries have implemented localized closures impacting millions of learners while most of the countries have implemented school closures nation-wide (UNESCO, 2020a). The pandemic has caused unprecedented levels of disruption to education globally. By 3 April, schools in 195 countries had been forced to close, affecting more than $91 \%$ of the world's student population" (UNESCO, 2020b). Below some Covid-19 countries are enlisted with their dates of school closures- starting locally if not applied countrywide at first- in addition to their main digital platforms with their qualities that played a central role in their Covid-19 Education Responses. These countries with the highest death rates are taken as examples among which Turkey has taken place for a very long time as a country with a high rate of mortality and infection cases. The data in the table belongs to the UNESCO website (UNESCO, 2020c). 
Table 1. Info on Several Covid-19 Countries' Education Response and Distance Education practices

\section{Brazil}

- $12 / 03 / 2020$ - localized school closure

- The MoNE has been criticized for not cooperating with GSM operators to provide disadvantaged students with the proper GBs to benefit from distance education at first.

- Municipal schools, state schools, and private schools took different steps in suspending classes and school-closures. There were schools cancelled at once, suspended, gradually suspended, or never suspended. Some schools and academies compensated the process of distance education or just canceled the term.

- Brazilian government provided an open educational content platform from preschool to university education:

- http://objetoseducacionais2.mec.gov.br

\section{China (K-12)}

- $16 / 02 / 2020$ - localized school closure

- The Chinese government come out the policy of "Learning never stops", which encourage educational department, institutions, teacher and students to adopt on-line learning platform and tools to realize remote teaching and learning on daily basis.

- Focused on providing a stable communication platform and effective broadband network, national cloud services which millions of Chinese students could learn at the same time on-line besides televised-learning by lessons on $\mathrm{tv}$, free cell phone data, and other services were used to supply a stable operation of distance education.

- During the pandemic, preschool education services were switched to on-line. Multimedia channels such as TV, radio, magazines, websites, and mobile apps have been used to support parents and teachers to engage with children learning at home. Also used TV to inform the teachers, parents, and the Ss.

- China has combined different strategies and has been using TV to inform parents, teachers, and students how to access educational content and tools on-line. 
France

- $03 / 03 / 2020$ localized, $16 / 03 / 2020$ county-wide school closure

- The Education Ministry's National Center for Distance Education (CNED) had started new e-learning and remote education in 2017 and it has been in use actively since then. It covered distance education content for students from kindergarten to high school.

- The government provided apps and platforms to continue with distance education:

- Ma Classe à la Maison: a virtual classroom system accessible via smartphones and computers, enabling teachers to facilitate the organization of distance learning. It also provides a range of pedagogical tools and the content is compatible with the national curriculum.

- Maison Lumni: a 52-minute daily program dedicated to students aged 8 to 12, produced in collaboration with the Ministry of National Education, broadcasted on France 4, France 2, and France 5.

- Teachers made use of common media tools like Zoom, Whatsapp, etc., or e-mail to communicate and instruct their students as well.

\section{India (applies K-12)}

- 04/03/2020- localized school closure

- Central Government of India declared the Pradhan Mantri e-Vidya Initiative for Digital Education in March 2020. It aimed at interconnecting all available efforts related to distance education types providing various forms of accessibility.

- e-Pathshala for providing e-books and related content

- DIKSHA - Platform for School Education

- MHRD-A collection of different platforms suggested by the Ministry of Human Resource Development for on-line learning during the health crisis.

- National Digital Library of India: an on-line library created by the Ministry of Human Resource Developmentnfor different levels of education, including lifelong learning.

- Cooperation with Swayam Prabha TV channels for distance education 


\section{$\underline{\text { Iran (applies K-12) }}$}

- $26 / 02 / 2020$ country-wide school closure

- Here are some distance education modes and channels provided by the Ministry of Education of Iran:

- SHAD: a learning management app provided by the Ministry of Education to assist learning during school closures.

-Shadweb.iranlms.ir: An application designed by the Ministry of Education to establish a social network for students

-Together for One Another: The Physical Education Department of the Ministry of Education in cooperation with the Islamic Republic of Iran Broadcasting has designed various programs for students for well-being and mental health, called Together for One Another.

- TV channels- Daily TV programs for all grades.

\section{Italy}

- 24.02. 2020 localized, on 10.03. 2020 country-wide school closures.

- The ministry of education started a page with the motto "La scoula per la scoula" :

https://www.istruzione.it/coronavirus/didattica-a-distanza.html

- Distance teaching was provided by schools over live classes by media tools like Whatsapp, Zoom, Google Suite, Facebook, Microsoft Teams, etc. apart from distance learning platforms including Rai Scuola, La mia Scuola differente, and Treccani Scuola with televised teaching.

- Provided resources supporting students with disabilities. 0-6 age group disabled students were considered as well.

- Designed webinars for teachers who also share their experiences during the process over Facebook. 


\section{$\underline{\text { Mexico }}$}

- $23 / 03 / 2020$ country-wide school closure

- Mexico can be speculated to have been fairly ready for distance education having present applications for distance education from $t v$ and on-line. Here are some portals and resources used for distance education:

- Aprende 2.0: resources promote the use of ICT to foster the development of digital skills provided by the Ministry of Education

- Aprende en casa por TV y en Línea: a program launched by the Ministry of Public Education of Mexico (SEP), a comprehensive remote learning platform that integrates TV, radio, internet, and mobile applications. It provides TV lessons and on-line resources to support learning a home. This program would transmit preschool, primary, secondary, and high school education content based on the Ministry of Public Education curricula.

- Libros de Texto: Digital versions of all free textbooks

- TELEsecundaria -the previously existing system of distance education programs for high school students in rural areas of the country.

\section{Russia}

- 11/03/2020- localized school closure

- Ministry set up a hotline to support urgent calls from smaller units of educational institutions for distance education.

- Russian e-school, Russian media tools, and platforms available for both teachers and students like Yandex.textbook, Teach.ru and Yaklass were supported by Russian IT companies technically.

-Edu portal: the Ministry of Education's official portal

- The ministry provided a TV program: My School On-line" broadcasting lessons and textbook content for secondary level students.

-Russian e-school: an open educational platform supported by the Ministry of Education of Russia

- TV channels: educational programs broadcasted on various national and regional channels in different subject areas, including preparation for secondary school graduation exams.

-Worldskills: a platform for digital skills development recommended by the Ministry of Education. 


\section{Spain}

- 11/03/2020- localized school closure

- Applied televised-teaching and distance e-learning platforms

- CIDEAD (Center for innovation and development of distant education) was active before the pandemics as well.

- The government provided platforms and resources like:

-Educlan: an on-line channel supported by the Ministry of Education that presents educational resources during the period of suspension of classes because of the coronavirus.

-INTEF: Ministry of Education pedagogical resources to support distance learning.

-Procomún: a collection of close to 100,000 educational resources and learning objects in different formats created by the Spanish Ministry of Education and Science with contributors to the educational community.

USA (applies K-12)

- 28/02/2020- localized school closure

- As the country has a state system, it differs in the application of distant education country-wide. But most of the states have their own educational precautions and agenda.

- Some states applied televised distance education in addition to on-line and other forms of remote learning.

Looking at the table above it is observable many of the countries above preferred localized school closures and among them mostly are the ones directed as divided into federal districts or governed by a state system. But looking at the process after the country-wide closures that generally occurred after 16.03.2020, the main channel of information flow was the internet itself both through the use of social media and broadcasting (radio-tv) tools and the websites as an on-line platform where students can reach the materials and resources prepared for the distant teaching processes many of which were planned in a flash due to the unprecedented phenomenon worldwide. Turkey was among the countries which started school closure country-wide with a prepared Covid-19 program shortly before the critical numbers of deaths rates came in place. 
Table 2. A Reinterpretation for the Figure "Multiple Delivery Channels for Remote Learning" in Innocenti Research Brief 2020-10 Report

\begin{tabular}{|l|l|}
\hline Delivery Channel & Percentage \\
\hline $\begin{array}{l}\text { Affordable distance education delivery channel for students from families with average inco- } \\
\text { me status }\end{array}$ & $\% 75$ \\
\hline Tv & $\% 58$ \\
\hline Radio & $\% 48$ \\
\hline Take-home & \multicolumn{2}{|l|}{} \\
\hline $\begin{array}{l}\text { Distance education delivery channels available for students from more-than-average income } \\
\text { status }\end{array}$ & $\% 7$ \\
\hline Home-visit & $\% 73$ \\
\hline Digital &
\end{tabular}

As can be seen from the data above taken from the Innocenti Research Brief 2020-10 (UNICEF, 2020a) rearranged in line with the measure of accessibility and affordability for the students from families with average income and more-than-average income by the author, mostly used and benefitted from and channel of distance education was TV content (\%78) prepared for a large range of grades including preschool distance education in countries like Turkey, Montenegro, Mexico, and some others.

As for radio broadcasting for distance education, it seems to be the most convenient and probably one of the cheapest means for reaching out to children who are the most disadvantageous option physically because of residing in mountainous areas, on islands, on poles, archipelagos, etc. Radio programs occupied a considerable place in Tanzania's Covid-19 Pandemic educational response: “UNICEF supported the Tanzania Institute of Education to develop home learning lessons currently being delivered through 36 radio stations and six television stations for all school levels from the pre-primary, primary, secondary and advanced secondary reaching 2.5 million children" (UNICEF, 2020b). There are some other examples like Cabo Verde, which uses radio dramas, lessons, tutoring, and other educational broadcasts to reach students on its 10 islands (GPE, 2020).

In Mexico, again, there is a huge difference between the living standards of indigenous children and the others: many indigenous households are in rural areas with limited or no internet connectivity. Access to effective distance learning platforms is problematic; also, countries with strong cultural diversity, like Mexico, should aim for these services to be culturally and linguistically pertinent. SEP (Ministry of Education) has broadcasted radio programs in an attempt to reach the most isolated indigenous 
communities, but even then, approximately $10 \%$ of school-aged indigenous children have reported that they do not listen to the radio or did not have access to the physical apparatus at home (UNESCO, 2020d). Considering this technological divide, most countries around the world are also using television and/or radio-based programs to implement distance education. Africa seems to be the most active in the efforts to leverage either TV or radio (70\%), some combining both (34\% of countries), while Europe and North America seem to be using less radio than other regions, yet very active in deploying TV-based distance education programs (UNESCO, 2020e).

Having the technology is not enough. Internet connection is often not good enough. As illustrated in the dashboard, $2 \%$ of Italian families have an internet connection between 2 and $30 \mathrm{Mbs}$, much lower than is required to download and stream educational content. This led the Ministry of Education to sign a protocol with Rai to diffuse education content in its Rai Scuola and Rai Play as part of a campaign, \#LaScuolaNonSiFerma (The school never closes) (UKFIET, 2020). Besides, according to the aforementioned Innocenti Research Brief 2020-10, almost half of the 127 attending countries with the percentage $48 \%$, included take-home content for distance education besides other channels and combinations of all. According to the data given home visit was another way of compensating the educational need at the time of the school closures resulting from the pandemic. While TV-Radio, Digital Platforms-TV, TV-Radio-Digital Platforms, TV-Take-home, TV-Radio-Digital Platforms, vice versa and various combinations of all these including home visits were probably available together in many participating Covid-19 countries in the process depending on their situations in their national responses (UNESCO, 2020a).

\section{Some Details and Difficulties Experienced in Distance Education in Turkey and Some Other Countries}

Turkey started a county-wide school closure and MoNE supported that each school is in constant contact with its own students especially over EBA ${ }^{2}$ (Education Computing Network in Turkish) platform and other communication technologies like Zoom, Microsoft teams, etc. for live classes to make sure on-line education continues. Education for K-12, VET schools, and higher education was suspended for all students for seven weeks as it was in many other countries in the world. Immediately after the first week, on March 23, the Ministry of National Education (MEB) launched "distance learning" lessons and "virtual classroom" practices via TRT-EBA TV ${ }^{3}$ and EBA. The platform worked like a base where all the digital teaching and learning took place and

\footnotetext{
2 Education Computing Network is an educational content network established and monitored byTurkish NMoE. It was designed and operated by the Ministry of Innovation and Educational Technologies General Directorate in 2012 and has been actively used in almost all the educational processes of public and private schools in Turkey. Network mentioned can be reached from: https://www.eba.gov.tr/\#/anasayfa.

3 TRT is the abbreviation for Turkish Radio and Television Corporation.
} 
directed from. After a certain period of time, aside from information technologies like zoom, Microsoft teams, etc. EBA Live Class applications have become the main source of on-line teaching for almost all kinds of schooling all over Turkey. MoNE declared that school would be suspended and distance education would start the process providing a plan combined of:

* TV Education: Broadcasting from EBA Television channels broadcasting was planned for grades 1-12 grades at different times, for two hours a day.

* Asynchronous Education: Using the EBA by the student on its own.

* Synchronous Education: EBA Live Classroom where teachers and students can meet online according to a program (TEGV, 2020).

Educational systems were mostly unprepared for the sudden and unprecedented results which malnutrition, bad accommodation and sheltering, insecure life-standards in social environments especially for children in disadvantaged families, less access to water and sanitation, etc. Therefore, school closures not only meant a sudden halt for education in person and unexpected difficulties to get over pedagogically and digitally, but also a load of many other negativities for students who are only able to reach these facilities only at regular schooling institutions they were enrolled, especially if these institutions were boarding schools. Here other some others to count for Turkey and in other Covid-19 countries:

Lack of Equipment and Internet Accessibility: In countries like USA, Italy, Germany that consist of multiple federal republics, regions, or states, mostly unified action didn't come early in school closures. For example, Ohio was the first state to declare school-closure, so the school closures started locationally in the USA. As each region or state often happen to have their own national curriculum or educational agenda/ program in these kinds of countries, it was difficult for many of them to provide an on-line and nation-wide applicable program for distance education. In these cases, many of the administrations initially preferred to publish guides for teachers/ parents, schedule regular teacher training webinars or on-line programs to conduct and monitor the process smoothly as they did in Italy. In USA, some approaches have been applied in school closures like state recommended and state ordered cancellations in the academic year. School term cancellations showed themselves on different terms like "varied by school districts", "ordered closed for the academic year", "ordered closed until further notice", "recommended by the state". The USA was one of the most disadvantaged for battling with the virus due to its immense population and uneven life standards over the country with various forms of social inequalities that would eventually reflect itself on the distance education process to arrive soon. One of the main problematic areas that differed the level of efficacy of distance learning and remote learning was the ability to implement digital literacy besides physical adequ- 
ateness in affording a decent flow of internet and software necessary to implement the distance learning process and its materials to benefit. Malnutrition could be another negative outcome in American education after Covid-19 due to the low income of many Americans whose children mostly had the chance of being fed regularly only by the food provided by the school administrations. "In the USA, an estimated $2.5 \%$ of students in public schools do not live in a stable residence. In New York city, where a large proportion of COVID-19 cases in the USA have been observed, one in ten students were homeless or experienced severe housing instability during the previous school year" (Van Lancker and Parolin, 2020). The US government education office didn't provide common internet platform for the distance education process during Covid-19 time. Instead, the states have dealt with the education at the time in their own ways as there have been almost 12 billion American students without access to internet in their homes. In New York, the country's school district there is stated to be 114 thousand children don't have a regular home, many of them live in the shelters set up for homeless children. A study from the Associated Press found that $17 \%$ of U.S. students do not have computers in the home and 18\% of students lack access to high-speed internet (Beyazova et al., 2020).

Many states tin the USA took their initiatives about compensating the digital inequalities considering tv as an effective channel a fairly convenient way of reaching the disadvantaged students. For instance, Washington, L.A., Bethlehem, Pennsylvania is known to have created partnerships with local PBS stations to repurpose existing programming and air segments for certain grade levels at specified times (USA TODAY, 24. 07. 2020).

In Italy, again, affordability and remoteness can compound difficulties. Some regions have devoted specific financial allocations to enable poorer families to buy the equipment necessary for distance learning. In Sicily, for example, each lower and upper secondary school can give an allowance for laptops, tablets, and devices to students from low-income families (UKFIET, 2020).

In Turkey, Refugee families, including Syrians, in addition to language barriers, often the lack of technological equipment that limits their access to distance education and related broadcasting materials. It can be estimated that these difficulties in accessing distance education via EBA may increase the risk of refugee children's breaking away from the education system. According to a recent pre-investigative report about refugee children benefitting from their rights, some of the children participating in the study can follow EBA regularly, others share that they can follow the courses occasionally or not at all. The reasons for not being able to watch the lessons are not having tools such as television or computer or accessing the lessons via internet connection. Few children share that they don't have enough equipment to watch lessons at home (Beyazova et al., 2020). 
According to another recent report by SGDD-ASAM (abbreviation for the Association for Solidarity with Asylum Seekers and Migrants in Turkish) administered on 126 people registered in the database, $70 \%$ of the Education Sector Survey participants stated that their children are still enrolled in school. However, it was stated that $48 \%$ of the children enrolled in school could not benefit from distance education. More than half of the families of children who have difficulty in participating in distance education stated that technical facilities such as television and computer access were insufficient as the reason for not being able to benefit from distance educational opportunities (SGDD, 2020). Hence, internet access, internet infrastructure of the country in question, the vicinity of $\mathrm{Ss}^{\prime}$ residences can be counted among accessibility items.

Content and Material Quality: Countries that were experiencing accessibility and similar physical problems as we mentioned above have already had their solutions in distance education. As for cultural difficulties for multinational countries, it was important to provide educational materials culturally attending, inclusive, and sensitive which was also adapted to all cultural diversities, ethnicities, and languages spoken in the region. For instance, talking about indigenous children's distance education, while it may not be possible to translate all distance learning resources into indigenous languages quickly, the government and civil society must continue ensuring that materials, beyond textbooks, are available in languages other than Spanish, even after children return to school. Otherwise, more indigenous individuals may decide to abandon their tongue in favor of Spanish. They may feel that preserving their language will put them at a disadvantage or increase their cost of accessing fundamental services (AGKOM -Autorità per le Garanzie nelle Comunicazioni, 2019).

For countries like Turkey, housing thousands of migrants and refugees it would also be problematic to attend to those migrant students who already have difficulty adapting to enroll in Turkish schools without sufficient knowledge of Turkish in terms of following distance education on-line. Circumstances in the time of pandemic and distance education were "especially challenging for children of refugees who are also struggling to tune in the school system of Turkey and also have difficulty with language barrier because of which parents can hardly support them in their education in Turkey". Education Information Network (EBA), teachers offer a distance education model that uses video recorded (AA, 2020). Disabled students and students with special needs were other topics upon which a national common practice wasn't mostly available. What many administrations preferred to provide for these was preparing web portals where a great deal of pre-existing relevant materials and quickly prepared effective some new ones were gathered as a source.

1. Time Limit: Another difficulty in distance education in the pandemic process was to prepare a schedule, produce distance education content applicable and qualified in a short time. Many countries benefitted from platforms and open educational 
resources while there were some which cooperated with related companies as the situation required cooperation between educators, educational experts, and digital content producers and programmers for effective programs to be created, monitored, and evaluated. Turkey started preparing distance education content, material, and a steady schedule to be broadcasted on Tv and reached over EBA shortly before the pandemic caused school-closures. After school-closure on March 16, 2020, MoNE informed the distance education process would take place after a one-week holiday. It was such a limited span of time for preparing systematic content and on-line/broadcasting material. According to MoNE data, shootings were made in 10 different studios in Ankara and Istanbul for TRT EBA distance education broadcasts. 674 teachers from 93 branches took part in the shootings, 221 event videos were prepared with 2 thousand 358 lecture videos (AA, 2020).

2. Preparedness On Behalf of the Instructors and Teachers: Aside from physical and cultural difficulties, it was also a problematic area for many countries to adapt to teachers, students, and parents to on-line teaching situations. Especially for countries with teachers of old ages is great in number and with teachers not so familiar with technological teaching practices lots of effort needed to be made, webinars were arranged, school administrations were requested peer-learning (young teachers assisting the elders getting into using the technological teaching practices, in-service training organized on-line, etc.). It was important to get them involved as the educational content prepared for national use in audio-visual media formats was not available. This made a great number of teachers in many Covid-19 countries create their own content to continue from where they left teaching in person, to be used in live on-line classes or to be delivered by e-mails and on-line communication tools as well. In a survey carried out in Brazil, an option that states the surveyor took courses at distance education for education or work gave the result of which only $12 \%$ of people actually did. In the ICT Education report which was published in June 2020, which aims to understand the access, use, and appropriation of ICTs in private and public schools. $14 \%$ of public schools declared to have used a platform or digital learning environment while the number for private schools was $64 \% .58 \%$ of the students declared to have used a cell phone for school activities $18 \%$ of which only have mobile access. $33 \%$ of teachers said that they had involved in certain trainings for using the computer and the Internet for school activities (Parreiras \& Mourão, 2020). According to the Authority for Communications Guarantees, in Italy before the Covid-19 outbreak; only in $0.5 \%$ of schools there was no teacher using such technologies at all (UKFIET, 2020).

Schools where technology was already part and parcel of teaching - mostly at the upper secondary level - were obviously better prepared when school closures happened. Whether it is adequate for providing an effective distance education at the time of school closures is subjective; but there was, at least, a certain level of familiarity for the 
use of distance teaching and learning "Besides, although the digital register permits direct communication between schools and families, $10 \%$ of schools do not have the necessary equipment. A 2019 report showed that $47 \%$ of Italian teachers were using digital tools on a daily basis, $27 \%$ weekly, $14 \%$ a few times per month, $7 \%$ a few times per year, and 5\% never used them (UKFIET, 2020).

\section{Attendance, Autonomous Learning, Monitoring and Evaluating the Distance}

Education: Distance learning in the process of school-closures required students to obtain a steady and constant devotion to a certain level of self-study and attendance distance education schedule provided by the ministries, schools or individually by teachers to continue the curriculum they followed. In many countries and in Turkey one of the main challenges was to monitor the on-going distance education process as it was also difficult to make sure majority of students participated the on-line and broadcasting sessions provided on EBA or by their school. Teachers and instructors were performing on-line teaching hard in this process by assigning their students over EBA portal, giving lectures, having live classes and problem- solving sessions. So to find out how useful and effective the period was, predictively possible over on-line assessment and evaluation tools. According to a survey carried out by TEGV (Education Volunteers Foundation of Turkey in Turkish), limited with students enrolled in only public schools and only had EBA platform and EBA TV as distance learning resources. Students' follow-up frequency was $11 \%$ for live on-line classes, $83 \%$ for EBA TV broadcasts and $47 \%$ for watching related videos provided for each grade on daily basis (TEGV, 2020). MoNE conducted educational attainment evaluation applications on-line at the beginning of July. The application was aimed at students studying in the 5 th, 6 th, 7 th and 9th, 10th and 11th grades of the public and private secondary and imam hatip secondary schools. Students took an on-line test, which were prepared in accordance with their grade levels, and could be attended from computers, tablets and mobile phones.

\section{Conclusions and Recommendations}

A certain level of attendance on the part of the students, a good control of the pandemic education response on behalf of the government and MoNE, a good guidance and parental monitoring for student attendance and academic studies especially if they are from K-12 grades were the key elements for the process to be effective on national levels. Each country has tried to manage the pandemic and monitor its results on education through its education response but the common practices mentioned in the study seems to be:

- announcing the school-closures, the start of the distance education programs, providing guidance for schools, teacher/instructors, and parents initially. 
- providing distance education channels like digital platforms: web portals, cloud learning devices, social media tools, media applications like Zoom, Whatsapp, Telegram, etc., mail, TV, radio, take-home contents, etc. and enlarging the variety of accessibility by diversifying the modes of the content (like televised, radio broadcast, sent, e-mailed, delivered, texted, teleconferenced content)

- monitoring the education provided bu on-line assessments or evaluation tools

- providing physical and economical support like cooperations with GSM operators for free GBs, SMSs, providing tablets, netbooks, TVs, radios to disadvantaged students.

To have a summarizing glance the situation of distance education after school closures in Turkey:

1. In Turkey, (MoNE) has attempted to provide a rapid response for distance education in pandemics. After the country-wide school closure in Turkey on March 16 , the ministry immediately offered the support of distance education via television for both students and the parents. MoNE provided free GB collaborating with GSM operators.

2. It took a fairly short time to prepare course contents for all levels of both primary, secondary and tertiary schools including content for preschoolers. The course contents needed in distance education were rapidly produced for all levels and moved to distance education platforms. Television broadcasts spread on weekends in the following days and started to be broadcast on weekends to support students preparing for university entrance and high school entrance exams.

3. Numerous psychosocial support programs have been developed and implemented rapidly to support students, parents, and citizens in the field of special education and guidance.

4. MoNE also provided teachers with opportunities like seminars on-line to equip themselves with novel professional requirements that can help them with the possible and potential distance education circumstances in the future.

5. MoNE has put VET and Vocational and Technical Anatolian High Schools in place at the time of pandemic making use of their production capacities which underlined their academic significance. 
6. In addition to distance education organized to complete the curriculum, summer learning over distance education was organized. Summer school content over the same distance education channels were prepared and put into practice from June 19 on- the official date for the end of the term.

But there are some topics to be considered to be included in the future and possible distance education plan and programs of MoNE in Turkey like:

- Inclusion of immigrant students who had a major hindrance in catching up with the distance education classes due to the lack of knowledge of the Turkish language needs to be held. Some extra on-line Turkish courses attributed to enrolled immigrant students over distance education can be taken into consideration by MoNE.

- The practical and interactional character of some subjects like Physical Education, Art, Handicrafts, Foreign Languages, etc. needing a different approach in programming which must be taken into consideration during distance education programming phases.

- More statistical and effective studies that need to be carried out to specify the number of students in need of physical, technical, and economical support which can give the government an idea about if a certain budget could be allotted in order to equip the students in need of economical and logistic support.

- Webinars about preparing curriculum content, on-line teaching pedagogy, knowledge of on-line applications and tools, parental guidance on effective controlling and monitoring the distance education period, etc. that could be benefitted as the only and the most effective way of guiding teachers and parents in the time of pandemic which should be compulsory at some level. 


\section{References}

BEYAZOVA, A., Nimmer, M., \& Sabbagh, L. (2020). Covid-19 sürecinde İstanbul'un Farklı Yerleşimlerinde Çocukların Haklarına Erişimi Araştırması: Tarlabaşı Örneği. İstanbul: SPI. Retrieved online: on 25. 07. 2020 from https://data2.unhcr.org/en/documents/download $/ 76636$

SGDD-ASAM (Sı ̆̆ınmacılar ve Göçmenlerle Dayanışma Derneği), (2020). COVID-19 Salgınının Türkiye'de Mülteciler Üzerindeki Etkilerinin Sektörel Analizi Mayıs'20. Ankara: SGDD.

PARREIRAS, C. \& Mourão, R. M. (2020). Digital inequalities and education in Brazil during the COVID 19 pandemic. Digital Culture and Education (ISSN: 1836-8301). Retrieved online: on 21.07.2020 from: https://www.digitalcultureandeducation.com/reflections-on-covid19/digital-inequalities-and-education-in-brazil?rq=inequalities.

VAN LANCKER, W., \& Parolin, Z. (2020). COVID-19, school closures, and child poverty: a social crisis in the making. The Lancet Public Health, 5(5), e243-e244.

\section{Online Refrences}

https:/ / en.unesco.org/covid19/educationresponse, "Education: From Disruption to Recovery", UNESCO, 18.07.2020.

https:/ / bangkok.unesco.org/content/building-back-better-national-response-and-recovery-plan-reopening-myanmars-schools, Building back better: National Response and Recovery Plan for reopening Myanmar's schools, UNESCO Bangkok, 17.07. 2020.

https://en.unesco.org/covid19/educationresponse/nationalresponses, National Learning Platforms and Tools, UNESCO, 23. 07. 2020.

https://reliefweb.int/sites/reliefweb.int/files/resources/IRB\%202020-10.pdf, Innocenti Research Brief 2020 -10, UNICEF,_21.07. 2020.

https://www.unicef.org/appeals/files/UNICEF_Tanzania_Humanitarian_Situation_Report_ No2_for_January_June_2020.pdf , Tanzania Humantarian Situtation Report No2, UNICEF, 20.07. 2020.

https:/ / www.globalpartnership.org/blog/school-interrupted-4-options-distance-education-continue-teaching-during-covid-19, School, Interrupted: 4 Options for Distance Education to Continue teaching during COVID-19, GPR Trasnforming Education Organization, 21.07. 2020.

https:/ /gemreportunesco.wordpress.com/2020/06/12/covid-19-pandemic-and-indigenous-and-non-indigenous-students-in-mexico/, COVID-19 pandemic and indigenous and non-indigenous students in Mexico, World Education Blog (UNESCO), 28. 07. 2020. 
https://en.unesco.org/news/learning-through-radio-and-television-time-covid-19, Learning through radio and television in the time of COVID-19, UNESCO, 21.07. 2020.

https: / tegv.org/dosyalar/covid-19-donemi-uzaktan-egitim-durum-degerlendirme-raporu. pdf, Covid 19 Dönemi TEGV Çocukları Uzaktan Eğitim Durum Değerlendirme Raporu, TEGV, 27. 07. 2020.

https: / www.ncsl.org/research / education / public-education-response-to-coronavirus-covid-19.aspx, Public Education's Response to the Coronavirus (COVID-19) Pandemic, NCSL (National Conference of State Legislatures), 22. 07. 2020.

https:/ / www.usatoday.com/story/news/education/2020/03/28/pbs-on-line-learning-lausd-coronavirus-school-closures-tv-fox/2925962001/, No Online Learning? With Schools Closed from Coronavirus, These Teachers Air TV Lessons, USA Today, 24. 07. 2020.

https://www.ukfiet.org/2020/covid-19-how-is-italy-copying-with-school-closure/, Covid-19: How is Italy Copyıng with School Closure?,_UKFIET (The Education And Development Forum), 22. 07. 2020.

https://www.agcom.it/documents/10179/14037496/Studio-Ricer$\mathrm{ca}+28$ - $02-2019$ / af 1 e36a 5 -e 866-4027-ab30-5670803a60c2 ? version $=1.0$ EDUCARE DIGITALE-Lo stato di sviluppo della scuola digitale Un sistema complesso ed integrato di risorse digitali abilitanti, AGCOM, 24.07. 2020.

https:/ / www.aa.com.tr/tr/egitim/turkiye-uzaktan-egitim-istatistikleriyle-dijital-dunyanin-listelerini-zorladi/1882614, Türkiye Uzaktan Egitim İstatistikleriyle Dijital Dünyanın Listelerini zorladı, AA (Anadolu Ajans1), 24.07.2020. 